Proc. Estonian Acad. Sci. Geol., 2005, 54, 3, 191-203

\title{
Recent investigations of the peculiarities of Vilnius relief dynamics
}

\author{
Regina Morkūnaitė and Algimantas Česnulevičius \\ Institute of Geology and Geography, Ševčenkos 13, 2600 Vilnius, Lithuania; morkunaite@geo.lt; \\ cesnulevicius@geo.lt
}

Received 26 May 2003, in revised form 22 November 2004

\begin{abstract}
The paper presents data about landslides which occurred in 2000, 2001, and 2002 usually after autumn or spring rainfalls (for example in June 2001 after the rainfall of $19.8 \mathrm{~mm}$ and in August after the rainfalls of 29.8 and $37.9 \mathrm{~mm}$ ). In terms of the surrounding relief genesis, sediments, and character of morphometry, landslides occurred in erosional relief $(60 \%)$ and in sandy loam sediments $(80 \%)$. Landslides were the most frequent in small high hills (height over $20 \mathrm{~m}$, slope length more than $100 \mathrm{~m}$, slope angle over $7^{\circ}$ ). Changes along seven levelling profiles, located in the erosional, icemarginal formations, and glaciofluvial relief types, are considered. Erosional transformations mostly took place in the upper and lower parts of the slopes, where up to $0.35 \mathrm{~m}$ of sediments were eroded or accumulated in two years. According to the relief stability coefficient (4.6), the Rasos-Ribiškès area was erosionally the most active.
\end{abstract}

Key words: landslide, slope stability, suffosion.

\section{INTRODUCTION}

Most of the papers devoted to urban problems interpret the city as an area of highly transformed nature - a specific ecosystem. The level of urban transformations depends on the geographical situation, local settings, and responsibility of administration and activity of the population.

According to the diversity of geomorphologic conditions the environs of the city of Vilnius have no equal in the Eastern Baltic glacial accumulation area. The territory of Vilnius represents four orographic regions. Their topography developed during the decay of one Mesopleistocene (Medininkai) and three Neopleistocene (Nemunas) glaciers. It was also affected by cryogenic, periglacial 
lacustrine, glaciofluvial, fluvial, and other processes (Basalykas \& Dvareckas 1981). The interesting geomorphologic framework of Vilnius attracted the attention of Russian and Polish geographers, geologists, and geomorphologists already at the beginning of the 20th century (Wollosowicz 1917, 1923; Rydziewski 1922).

The study of Vilnius relief dynamics (in the context of sustainable development) has revealed that water erosion changes the relief forms less (the gullies deepen up to $10 \mathrm{~cm}$ after one rainfall) than landslides. Landslide investigations started at the beginning of the 19th century. Systematic engineering-geological examinations of slopes in the city of Kaunas have been carried out by M. Kaveckis since 1937 and V. Riškus since 1965. An overview of the landslide studies in Lithuania is presented in Table 1. The results obtained are available in numerous publications (e.g. Žiedelis \& Masiulis 1969; Gaigalas et al. 1982; Mikšys et al. 1991, 2002; Valiūnas \& Baltrūnas 1998; Morkūnaitè et al. 2001-2002; Baltrūnas et al. 2003).

Important research work has been conducted in the last ten years, providing a basis for detailing the genetic types of Vilnius relief, its typification and regionalization, and use of the obtained results for assessing the stability of the relief and city landscape (Česnulevičius 1991, 2001). According to these studies the territory of Vilnius and its expansion zones includes seven genetic relief types: icemarginal (24\%), glaciofluvial (27\%), glaciolacustrine (13\%), erosional $(27 \%)$, aeolian (2\%), fluvial (5\%), and organogenic formations (1\%) (Česnulevičius 1999). Valiūnas (1993) and Šliaupa (1991) have compiled a geological-geotechnical map and a geopotential map of Vilnius and its environs (at a scale of 1:50 000). These works can be taken as an assessment of the ecological situation in Vilnius. They point out that slope erosion is an ongoing recent geological process generating ravines, which are especially abundant in erosional hilly terrains. Thoughtless earth works disturbing the slopes may entail landslides whose number has especially increased in the years 2000-2002.

The engineering-geological evaluation of the Vilnius territory (map at a scale of $1: 25000$ ) by K. Dundulis and R. B. Mikšys is one of the most representative works about the Vilnius relief (Dundulis \& Mikšys 1970). These authors distinguished six engineering-geological regions on the basis of the distribution of surface deposits under the soil cover. They also took into consideration the water regime of deposits, relief forms, and recent geological processes. As recent geomorphologic processes are changing in time and space, regular investigations of the slope angles of relief forms (which are not evaluated in the mentioned map) are required. Mikšys et al. (2002) consider the anthropogenic factors affecting the landslides: adaptation of land surface and construction on or near the slopes; incorrect planning on slopes; formation of artificial banks of water ponds; openpit quarrying of mineral resources, followed by violations of mining and drainage technologies; regulation of rivers and surface water flows; exploitation of groundwater and drainage of the territories; landfills and soil dumps; artificial slopes on the land surface and in water reservoirs; dredging and deepening of the seaport water area. 
Table 1. Summary of systematic investigations of landslides in Lithuania

\begin{tabular}{|c|c|c|c|}
\hline Researchers & $\begin{array}{c}\text { Time of } \\
\text { investigation }\end{array}$ & $\begin{array}{c}\text { Investigated } \\
\text { territory }\end{array}$ & $\begin{array}{c}\text { Completed work } \\
\text { and obtained results }\end{array}$ \\
\hline P. Masiulis, A. Žiedelis & 1960-1964 & $\begin{array}{l}\text { Nemunas outcrops } \\
\text { in the sector } \\
\text { Druskininkai- } \\
\text { Jurbarkas }\end{array}$ & $\begin{array}{l}\text { Determined the relation- } \\
\text { ships between the land- } \\
\text { slide width and slope } \\
\text { height as well as water } \\
\text { regime changes }\end{array}$ \\
\hline
\end{tabular}

K. Dundulis, R. B. Mikšys 1960-1970

R. B. Mikšys

V. Marcinkevičius,

R. B. Mikšys, V. Mikulènas

A. Gaigalas, M. Melešytè,

B. Karmaza

R. B. Mikšys, A. Gaigalas, D. Stulpinas, V. Vaitiekūnas

J. Valiūnas, V. Baltrūnas

B. Karmaza, S. Gadeikis

R. Morkūnaitè,

A. Česnulevičius, D. Bauža,

I. Baužienè, A. Bukantis
1998

1969-1999

1971

1999-2002

1982

1985-1987

Gondinga bog near the Babrungas River and Vilnia outcrops on the territory of Vilnius

The territory of Vilnius

The territory of Lithuania

Gondinga bog near
the Babrungas River

The environs of Kaunas

Landslides of Nemunas outcrops in the sector BirštonasPrienai

2001-2002

The territory of Vilnius
Characterized the landslides, typified the soil receptivity, typified the geological processes on the territory of Vilnius, compiled a scheme at a scale of $1: 25000$

Engineering-geological map of Vilnius

Classified the landslides, typified the conditions, grouped the safety factors

Introduced the types of gravitational processes

Evaluated the deformations of the hill-fort and their causes, made an engineering-geological evaluation of landslides on the hill-fort, recommended the engineering measures for stabilization of the bog

On the basis of the density of ravines and gullies determined the sensitivity of the territory

Determined the geological preconditions for and scale of landslides, recommended the measures for the protection and exhibition of outcrops

Characterized the landslides and indicated their causes, determined the dynamics of meteorological factors, evaluated the slope stability in standard polygon 


\section{THEORETICAL ASPECTS OF LANDSLIDE PROCESSES}

Mass movement takes place when the destructive forces exceed the resistivity of the slope material. Many methods of quantitative analysis of slope stability, explained by theories of soil mechanisms, are available (e.g. Ecckel 1958; Terzaghni \& Peck 1967; Carson \& Kirkby 1972; Statham 1975).

Landslides are multifactor processes. According to Kotlov (1978), the increasing anthropogenic loads change the processes of compaction and loosening of deposits. The gravitational subsidence and uplift of the Earth's surface as well as related mass movement take place on slopes and ramparts. No clear criteria exist for the distinction of the causes of landslide processes, therefore the judgments of different authors are contradicting. According to Yemel'yanova (1953, 1972), any process may be caused by a previous or following process or event. This leads to a conclusion that landslides may be caused by earlier processes, such as washout of the slope bottom, change in the properties of deposits due to suffosion or weathering or rise in the groundwater table. On the other hand, the geological structure of slopes, properties of deposits and groundwater represent the medium for the development of landslide processes. According to the last author, all favourable or unfavourable for landslides processes and phenomena can be referred to by the term "factor". We agree with these speculations. Yet, it should be pointed out that these factors are nominated in published sources. The mechanism of landslide processes is generalized in Yemel'yanova (1972), where she points out that due to the force of gravity the deposits endure the stress of overlying deposits. The slope destruction occurs when the tension shifting overcomes the resistivity of deposits. Shuster \& Kockelman (1996) suggest that landslides are an outcome of multi-stage dangerous natural processes when the initial event triggers the secondary ones. Frequently two or more natural dangerous processes are taking place simultaneously. Researchers of slope processes have pointed out that a landslide process may be caused by active tectonics, the action of watercourses and groundwater or the occurrence of particular meteorological events. Even if the triggering causes are certainly climatic, it is in any case difficult to assess the influence of single parameters, such as the total precipitation, average temperature, etc. Moreover, the response of a slope is influenced by the distribution of vegetation, steepness, aspects, altitude range, and land use (Borgatti \& Soldati 2002). Chandler (1970) and Statham (1975) point out that the impact of the substratum on the cause of the landslide process (e.g. slope angle ensuring the slope stability) is especially subtle. Kataoka et al. (1976) consider the influence of slope morphology on the type and intensity of landslides. Of particular importance for slope studies in urbanized areas are landslide velocities and volumes, groundwater outlets, and plasticity of water saturated soil masses. Of no least importance are loads caused by external factors, e.g., construction works on slopes.

Published papers concentrate mainly on causes, conditions, driving forces or factors of landslide processes and not on strict definitions, therefore the theoretical 
problems remain unsolved. As the mathematical expression of the interaction of many forces is lacking, they cannot be considered as factors but rather as causes, conditions, and agents. The forces causing landslides are often referred to as factors for convenience. This is a disputable issue because in specific geographical zones and local conditions the causes and driving forces are different.

\section{LANDSLIDES AND THEIR AMPLITUDES IN VILNIUS IN 2001-2002}

According to the data obtained from relief dynamics observation stations, and the existing factual material, more than 10 landslides occurred in 2001 and 2002 (Fig. 1), usually after autumn or spring rainfalls (e.g. in June 2001 after a rainfall of $19.8 \mathrm{~mm}$, in August after rainfalls of 29.8 and $37.9 \mathrm{~mm}$ ). From the point of view of surrounding relief genesis, sediments and character of morphometry,

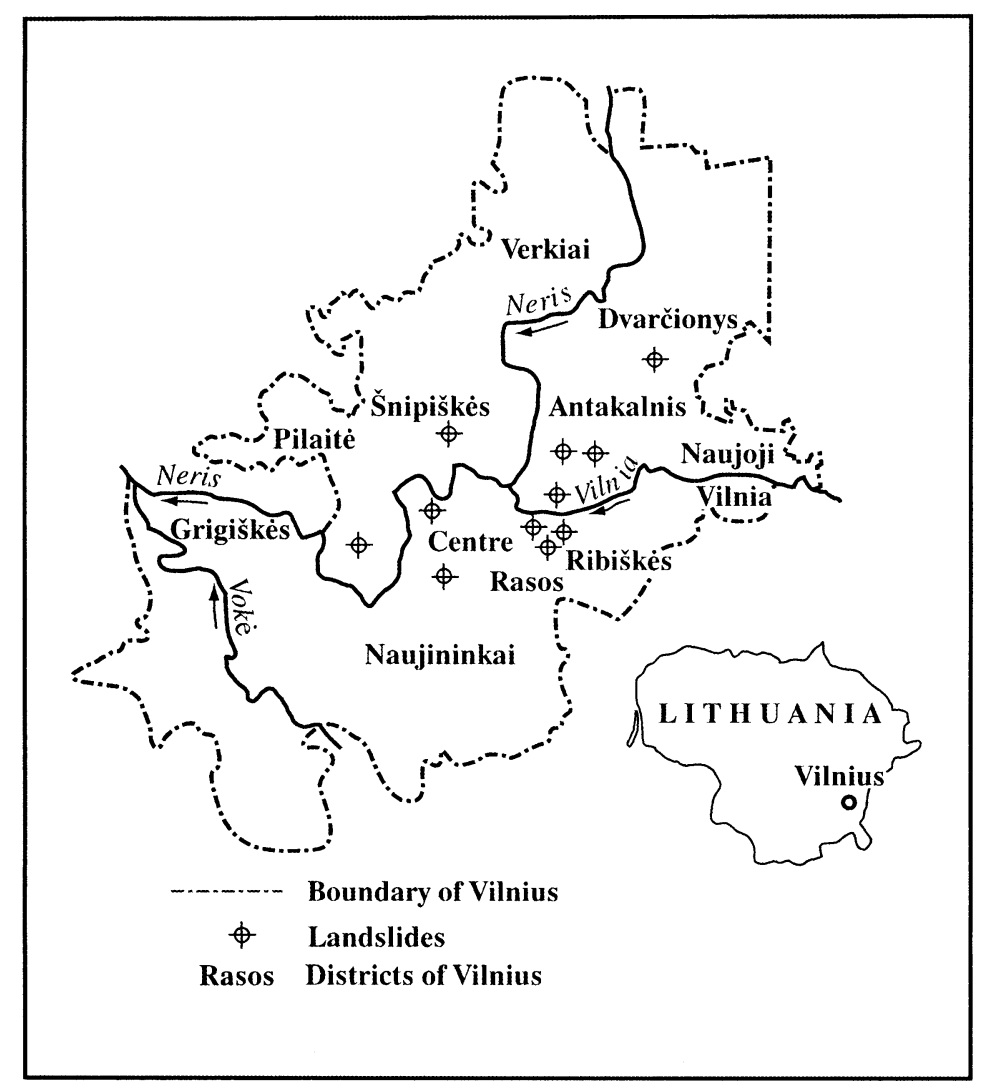

Fig. 1. Occurrence of landslides in the city of Vilnius in 2001-2002. 
most of the landslides took place in erosional relief $(60 \%)$ and in sandy loam sediments $(80 \%)$. From the point of view of morphometric areas, the landslides occurred in small high hills (height over $20 \mathrm{~m}$, slope length more than $100 \mathrm{~m}$, slope angle more than $7^{\circ}$ ).

Precipitation was not the cause of the substantial landslide, which occurred in glacial deposits (slope inclination $30^{\circ}$, slope height $25 \mathrm{~m}$ ) in the eastern part of Vilnius in August 2000. The soil with warehouses of ceramics moved down due to a high load and intensification of suffosion processes. The estimated economic losses were 5 million litas, whereas the slope reconstruction lasted for a year. The hydrogeological conditions were not responsible for the landslide. It was neglect of engineering requirements (the load and related intensification of suffosion) that caused the movement of soil, damage to the buildings, and blocking of the Dvarčionèle River by a 3-4 m thick soil layer. Although (according to documentation) the warehouses were planned as temporary buildings, storage of $11087.51 \mathrm{~m}^{3}$ of glazed tiles on an unstable slope was extremely risky, and the landslide proved this.

Somewhat larger landslides occurred in Sibiras and Ramunès streets in the spring of 2002. There is a relationship between higher precipitation, capacity of the rainwater drainage system, and surface inclination of the area. The mentioned streets are perpendicular to the railway (Vilnius-St. Petersburg) rampart with drainage pipes of large diameter installed to prevent the rampart from water erosion. When the drainage pipes were blocked, the rainwater flooded Sibiras and Ramunès streets and demolished the steep slopes with buildings. The resultant landslides inflicted damage on local residents by ruining the storehouses.

A landslide in Oslas Street occurred on 19-20 August 2001, as a result of improper reinforcement of the slope. The slope became unstable when the surface soil layer on the right side of the street had been scraped off. A strong rainfall washed the loose soil down onto the traffic part of Oslas Street.

The other landslides (in Batoras, Olandai, Zarasai, and Subačius streets) resulted from heavy rainfalls and damages to the rainwater drainage systems. These landslides were only local and produced no great harm to economy or public utility services.

The rainwater erosion has also produced new local relief mezoforms - ravines and gullies. We investigated these forms in Geležinis Vilkas Street and found that they had changed as a result of human activity. The largest ravine that caused damage was formed on the left bank of the Neris River in Antakalnis ward, perpendicular to P. Širvys Street, in July 2002. After a heavy rainfall $(50 \mathrm{~mm})$ a strong flow down the slope broke a concrete barrier, running into the Neris. It destroyed the slope and inflicted damage on traffic and individuals. This event was caused by street arrangement and underestimation of the destructive force of heavy rainfall and rainwater flow. In general, we can state that bad management often is the main cause of landslides and formation of ravines. 


\section{ANALYSIS OF DATA FROM LEVELLING PROFILES AND BENCHMARKED SLOPES}

To assess relief dynamics in the expansion zone of Vilnius in 2001-2002, seven cross-sections were developed in Ribiškès (two segments), Kairenai, Dvarčionys, Pylimeliai, Visoriai, and Traku Vokè. The cross-sections represent the erosional (Ribiškès), ice-marginal formations (Kairènai, Dvarčionys, Visoriai), and glaciofluvial (Pylimeliai, Trakų Vokè) genetic types of relief. The territory of Vilnius is divided into morphometrical types (Česnulevičius 1999). Both Ribiškès cross-sections are located in small high hills, Kairènai lies in large medium height hills, Dvarčionys in small high hills, Pylimeliai in medium size and medium height hills, Visoriai in small medium height hills, and Traku Vokè in undulating plain and small high hills. The Ribiškès area is dominated by sandy loam-sandy, Kairènai by sandy, Dvarčionys by sandy loam sandy, Pylimeliai by sandy, Visoriai by loamy, and Trakų Voké by sandy loam and sandy formations. The cross-sections of the Ribiškès area cross fallow meadows and a fresh outcrop (Fig. 2). The Kairènai cross-section runs across a slope overgrown with pines and a hayfield. The Dvarčionys geomorphic cross-section is located on a steep slope of a meadow overgrown with shrubs. The Pylimeliai cross-section crosses an anthropogenically-transformed meadow, part of which grades into a ravine. The Visoriai cross-section crosses a meadow slope. The Traku Voke cross-section extends along an abandoned ploughed field, where intensive building of private houses is going on.

The considerable surface transformations in all cross-sections recorded in 2001-2002 were mostly related to human activity. Cross-section 1 in Ribiškès

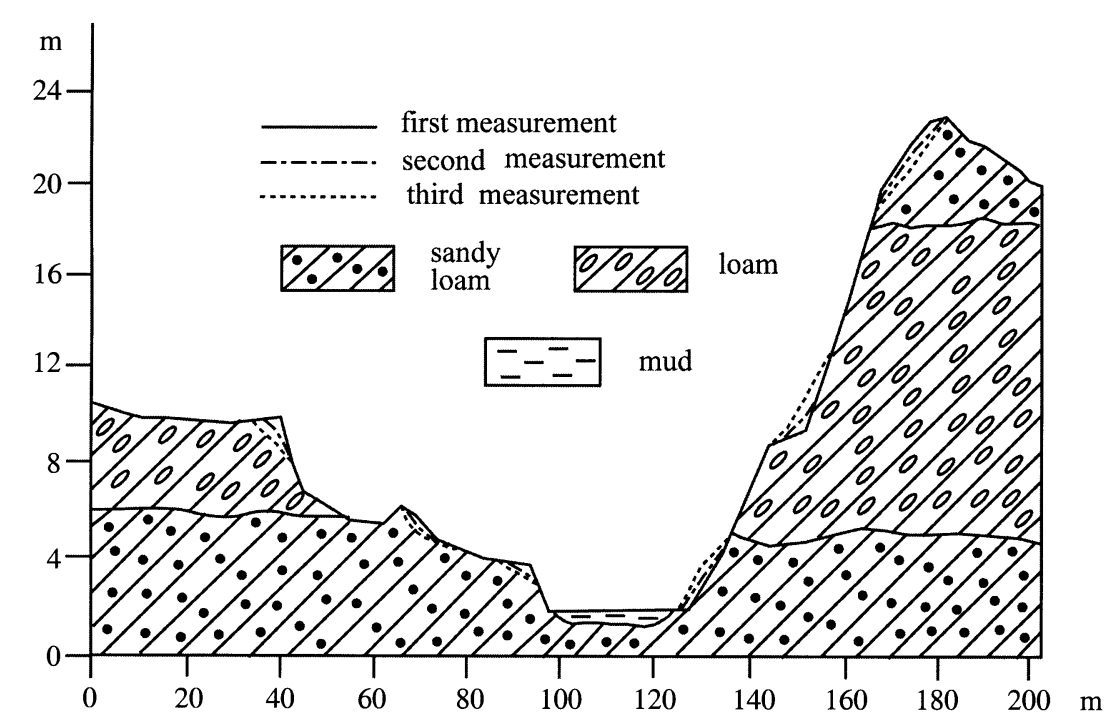

Fig. 2. Levelling profile with changes in topography in Rasos-Ribiškès erosional hills (for location see Fig. 3). 
runs through a steep hillside, a water-saturated flat-bottomed gully with ponds and on average height with a terraced hill (Fig. 2). The more than $30 \mathrm{~cm}$ thick surface layer was eroded on the steep slope in Ribiškès 1 cross-section during two years. In the same years an artificial earthwork, $0.7 \mathrm{~m}$ high and $8 \mathrm{~m}$ wide, was made in the urbanized territory of the same cross-section. It was designed to reduce the surface water runoff from the unpaved road. Despite these measures, in two years a $25 \mathrm{~m}$ long and $0.4 \mathrm{~m}$ deep gully was eroded below the earthwork.

The Ribiškès cross-section extends along the road excavation in the slope and through a fresh outcrop. During the two years soil was piled up in the upper part of the outcrop, and till and sand were excavated in its lower part. Due to this kind of activity the upper edge of the outcrop "accreted", whereas the lower part retreated and became deeper. The outcrop became even more unstable than it had been.

The Kairenai cross-section includes a slope of ice-marginal formations (Dvarčionys plateau), descending into a glaciofluvial terrace plain. The changes in the relief in the Kairenai area are also related to piling up of soil in the upper part of the slope and excavation works in its lower part. During two years a $0.2-$ $0.3 \mathrm{~m}$ thick soil layer was piled up in the upper part of the slope. Considerable surface changes in the lower part of the slope were related to soil storage. Before our investigation, an earthwork $0.8-1.0 \mathrm{~m}$ high was built in the upper part of the slope. In two years it was completely removed and replaced by a $0.5 \mathrm{~m}$ deep excavation.

The Dvarčionys cross-section includes part of the slope of the Dvarčia River valley. The slope has been transformed by man and partly reinforced (water drainage gutters have been installed). The eroded layer in the upper part of the Dvarčionys profile slope is somewhat thinner, only $0.1-0.2 \mathrm{~m}$. A flat debris cone has begun to develop in the lower part of the slope. In two years it has reached the height of $0.2-0.3 \mathrm{~m}$. The lower part of the debris cone borders on the Dvarčia River channel. After heavy rainfalls sand, gravel, and even shingle are transported into the river.

The Pylimeliai cross-section includes the bottom of the Lyglaukiai morainic massif, which grades into the glaciofluvial terrace surface. The greatest surface transformations in the profile have occurred in the upper and lower parts of the slope. A $0.2-0.4 \mathrm{~m}$ thick layer of sandy sediments accumulated in the upper part of the slope during two years. As a result of erosional processes the lower part of the slope retreated by $8 \mathrm{~m}$, considerably increasing the slope inclination and thus creating favourable conditions for further slope erosion.

The Visoriai cross-section includes the slope of a medium size and medium height hill belonging to ice-marginal formations. The $0.2-0.3 \mathrm{~m}$ thick soil layer in the upper part of the slope was eroded during one year. The slope erosion stopped in 2002. No surface transformations were recorded in the spring and autumn of 2002. In the middle part of the slope (at the break edge) cross-section transformations occurred in the years 2001-2002. The eroded layer was $0.6-0.8 \mathrm{~m}$ thick. Erosion took place when this area was being prepared for construction works. An about $0.3-0.4 \mathrm{~m}$ thick soil layer was piled up in this place in the summer of 2002 and part of it rolled down the slope. 
Table 2. Surface transformations in the investigated areas

\begin{tabular}{l|c|c|c}
\hline \multicolumn{1}{c}{ Cross-section } & \multicolumn{3}{c}{ Relief transformations, m } \\
\cline { 2 - 4 } & Minimal & Maximal & Average \\
\hline Ribiškès 1 & 0.0 & 1.1 & 0.05 \\
Ribiškès 2 & 0.0 & 1.2 & 0.13 \\
Kairenai & 0.1 & 1.0 & 0.05 \\
Dvarčionys & 0.2 & 0.4 & 0.04 \\
Pylimeliai & 0.2 & 2.2 & 0.11 \\
Visoriai & 0.0 & 0.6 & 0.02 \\
Trakų Vokè & 0.1 & 2.0 & 0.08
\end{tabular}

The Traku Vokè cross-section includes the surface of an undulating glaciofluvial plain grading into a flat-bottomed erosional gully. The upper part of the slope was most strongly eroded. The soil layer eroded during the preparation of the construction area was up to $1 \mathrm{~m}$ thick. A hillock $2 \mathrm{~m}$ high and $20 \mathrm{~m}$ wide was piled in the upper part of the slope in the autumn of 2002. This hillock will, presumably, be removed after the end of the construction works. The thickness of the eroded layer in the lower part of the profile is $0.3-0.6 \mathrm{~m}$.

According to the levelling data a $0.2-0.4 \mathrm{~m}$ thick layer was eroded in the transformed and partly reinforced (with drainage gutters) slope of Dvarčionys plateau. The layer eroded in the steep slope in the erosional relief (Rasos-Ribiškès terrain) was $0.3 \mathrm{~m}$ thick. The earthworks $0.7 \mathrm{~m}$ high and $8 \mathrm{~m}$ wide have been designed to reduce the surface water runoff from the unpaved road (Table 2).

\section{EROSIONALLY ACTIVE PARTS OF THE VILNIUS AREA}

The obtained results have practical significance. They represent the values of slope stability and composition of unstable slopes (Fig. 3). Territorial stability may be estimated through the stability of slopes. The slope stability is described by the coefficient

$$
\eta=N_{\mathrm{f}}+c l / T,
$$

where $N_{\mathrm{f}}$ is the friction force, $c$ is soil cohesion force, $l$ is the area of affected plane surface, and $T$ is the gravitation force. As the length of the slopes of Vilnius does not usually exceed $70 \mathrm{~m}$, the above formula may be adapted by elimination of the plus sign. This is especially important when boreholes are located in one part of the slope - upper, middle, or lower. When $\eta>1$, the slope is stable, when $\eta=1$, the slope is in a marginal state, when $\eta<1$, the slope is unstable. 


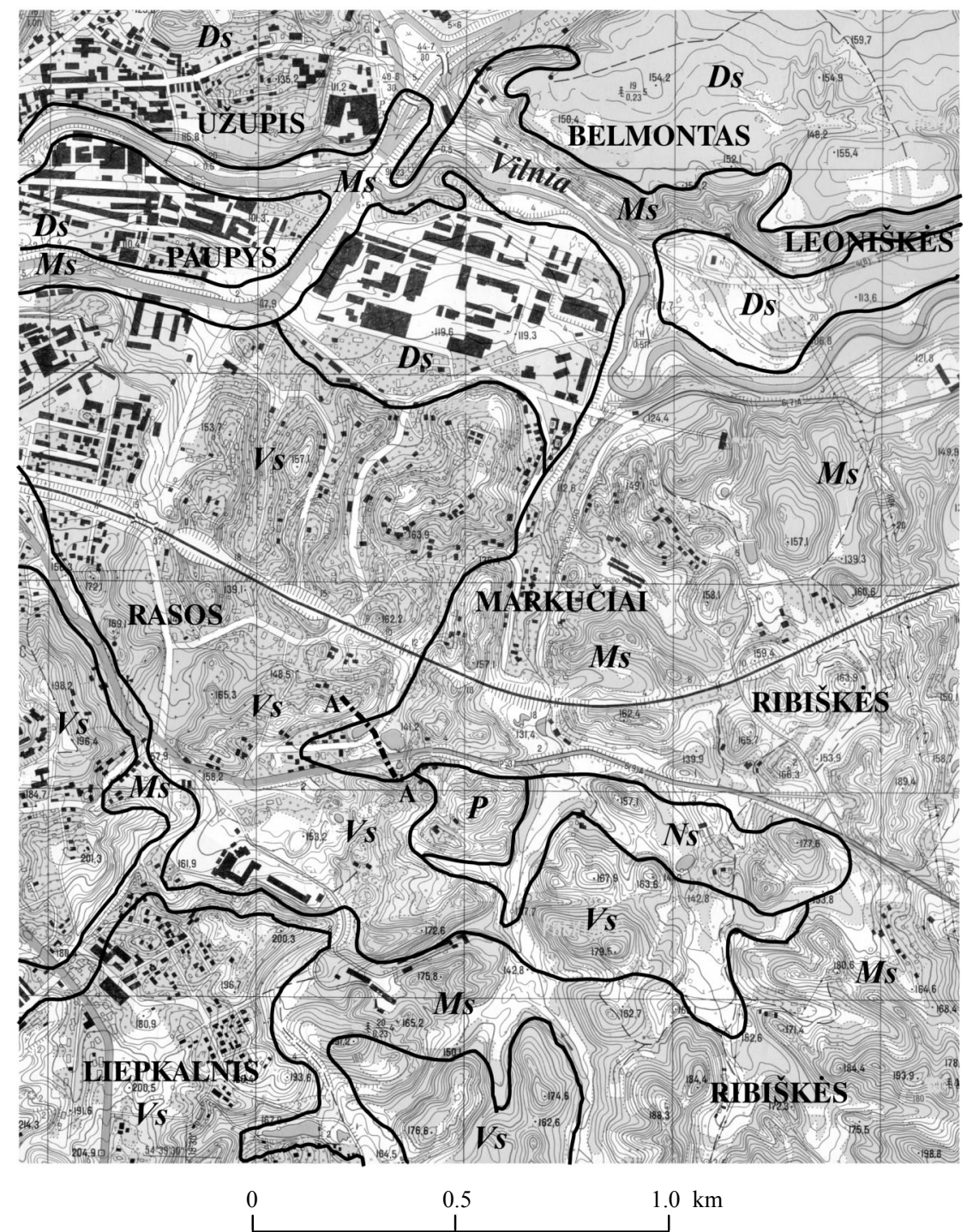

Fig. 3. The slope stability areas of Rasos-Ribiškès erosional hills: Ns, unstability; Ms, low stability; Vs, medium stability; P, stability; Ds, high stability; A-A, levelling profile.

This coefficient may be derived from values of cohesion $\left(c, \mathrm{~kg} / \mathrm{cm}^{2}\right)$ and angle of internal friction ( $\phi$, degree), available for this territory in tables with mean values compiled by experts (Dundulis \& Mikšys 1970).

The determined slope stability coefficients and different stability boundaries (Fig. 3) in the Rasos-Ribiškès erosional hilly terrain - covered by intermorainic aqueoglacial sandy sediments of the Medininkai-Grūda stage - revealed the dominance of medium stability (coefficient values 1.0-1.25) areas composed of 
fine-grained sand of average density and plastic clayey loam. For example, in the topographic plan (at a scale of $1: 2000$ ) of the investigated area the stability coefficient calculated by the adapted formula is 4.6 for a $120 \mathrm{~m}$ long slope sector, whose homogeneousness in terms of morphogenesis is proved by the contour line. The slope angle determined on the basis of the topographic map is about 12 degrees. The implication is that these slopes (of analogous morphogenesis, angle, and height) are stable when not under extra anthropogenic loads (moreover, they are single-layered in terms of lithology; loam begins only at a depth of $8 \mathrm{~m}$ ). In Fig. 3 the areas of the Ribiškès erosional hilly terrain, grouped according to slope stability, are shown in a fragment of the topographic map (at a scale of $1: 10000$ ).

\section{CONCLUSIONS}

1. The mechanism, causes, and conditions of landslide processes are an open issue, especially in Lithuania, where there are few researchers of this field. In the years 2001-2002 landslides mostly affected the relief of the city of Vilnius. The landslides were caused by heavy spring and summer rainfalls, excavations at slope bottoms, damage to the drainage system, etc.

2. The changes, determined on the basis of levelling data obtained from seven cross-sections in erosional (Ribiškès - two sections), ice-marginal (Kairènai, Dvarčionys, Visoriai), and glaciofluvial (Pylimeliai, Traku Vokè) reliefs of Vilnius expansion zones, are mostly predetermined by economic activity (excavations, earth works). Erosion-caused transformations occurred mostly in the upper and lower parts of the slopes - in two years about $0.2-0.35 \mathrm{~m}$ thick layers eroded or accumulated. The greatest transformations of $0.3 \mathrm{~m}$ were recorded in the thickness of the eroded layer in the steep slope, where the earthworks were planned $0.7 \mathrm{~m}$ high and $8 \mathrm{~m}$ wide, and in the glaciofluvial Pylimeliai relief, where the lower part of the slope retreated for about $8 \mathrm{~m}$.

3. The determined slope stability coefficient and boundaries of different stabilities in the mostly erosionally active Rasos-Ribiškès hilly terrain, covered by intermorainic aqueoglacial sandy sediments of the Medininkai-Grūda stage, revealed the dominance of medium stability (coefficient values 1.0-1.25) areas composed of fine-grained medium density sand and plastic clayey loam.

\section{REFERENCES}

Baltrūnas, V., Dundulis, K., Karmaza, B. \& Gadeikis, S. 2003. Character of erosional landslide processes in the region of the large meanders of the Nemunas river. J. Environ. Eng. Landscape Management (Vilnius), 11, 100-109.

Basalykas, A. \& Dvareckas, V. 1981. Vilnius city environs in terms of geomorphology. Geography (Vilnius), 17, 3-40.

Borgatti, L. \& Soldati, M. 2002. The influence of Holocene climatic changes on landslide occurrence in Europe. In Landslides (Rybar, J., Stemberk, J. \& Wagner, P., eds.), pp. 111-116. Balkema. 
Carson, M. A. \& Kirkby, M. J. 1972. Hillslope Form and Process. Cambridge University Press, Cambridge.

Chandler, R. J. 1970. The degradation of loess clay slopes in an area of the East Midlands. Quart. J. Eng. Geol., 2, 161-181.

Česnulevičius, A. 1991. Quantification of soil erosion risk in the Lithuanian uplands. In The Geographical Yearbook, Vol. 27, pp. 5-14. Institute of Geography, Vilnius.

Česnulevičius, A. 1999. The Relief of Lithuania: Morphographic and Morphometric Aspects. Institute of Geography, Vilnius.

Česnulevičius, A. 2001. Evaluation of geodynamic processes: methodic aspects. Geography (Vilnius), 37, 2, 5-11.

Dundulis, K. \& Mikšys, R. B. 1970. Inzhenerno-geologicheskie usloviya territorii g. Vil'nyusa. A report, Geological Survey of Lithuania, Vilnius (in Russian).

Ecckel, E. C. (ed.). 1958. Landslides and Engineering Practice. Washington.

Gaigalas, A., Melešyte, M. \& Karmaza, B. 1982. The gravity processes in the valleys of Lithuania rivers. In The Geographical Yearbook, Vol. 20, pp. 139-148. Institute of Geography, Vilnius.

Kataoka, J., Takeda, Y. \& Lida, O. 1976. A study of landslides on concave slopes. J. Jap. Forest Soc., 58, 6, 222-224.

Kotlov, F. B. 1978. Changes of Geological Environment Under the Impact of Human Activity. Nedra, Moscow (in Russian).

Mikšys, R. B., Gaigalas, A., Stulpinas, R. \& Vaitiekūnas, V. 1991. Slope deformations in the Gondinga archeological site: cultural, geological and engineering geological aspects. In The Geographical Yearbook, Vol. 27, pp. 185-191. Institute of Geography, Vilnius.

Mikšys, R. B., Marcinkevičius, V. \& Mikulènas, V. 2002. Human factors in landsliding processes of Lithuania. In Landslides (Rybar, J., Stemberk, J. \& Wagner, P., eds.), pp. 251-254. Balkema.

Mikšys, R. B. A. 1971. Engineering Geological Conditions in the Territory of Vilnius City. Dissertation for the degree of candidate of geological-mineralogical sciences. Leningrad (in Russian).

Morkūnaitè, R., Česnulevičius, A., Bauža, D., Baužienè, I. \& Bukantis, A. 2001-2002. Analysis of Vilnius Relief Dynamics in the Context of Sustainable Development. Report on research work, Institute of Geography, Vilnius.

Rydziewski, B. 1922. Rys geologiczno-morfologiczny Wilna. Ziemia, Wilno.

Shuster, R. L. \& Kockelman, W. J. 1996. Principles of landslide hazard reduction. Special Report. Transportation Research Board, 247, 91-105.

Šliaupa, A. 1991. Preparation of cartographic ecologeological model of Vilnius city (M 1:50000) and district on the basis of geological data. Manuscript, Geological Survey of Lithuania, Vilnius.

Statham, I. 1975. Slope instabilities and recent slope development in Glenculen, County Wicklow. Irish Geogr., 8, 42-54.

Terzaghni, K. \& Peck, R. B. 1967. Soil Mechanics in Engineering Practice. Wiley \& Sons, New York.

Valiūnas, J. \& Baltrūnas, V. 1998. The problems of slope management and protection in Kaunas city. Geology (Vilnius), 23, 165-172.

Valiūnas, J. 1993. Assessment of the Ecological Situation of Vilnius City and Environs. Report, Geological Survey of Lithuania, Vilnius.

Yemel'yanova, E. P. 1953. Causes and factors of landslide processes. In Voprosy gidrogeologii $i$ inzhenernoj geologii, pp. 67-81. Nedra, Moscow (in Russian).

Yemel'yanova, E. P. 1972. Main Patterns of Landslide Processes. Nedra, Moscow (in Russian).

Wollosowicz, S. 1917. Okolice Wilna pod wzglcedem ewolucyjno-morfograficanym. Wilno.

Wollosowicz, S. 1923. O grzædach morenowych ziemi narockiej i granicy mlodszego zlodowacenia na dorzeciu Wilji. Sprawozdania Panstwowego Inst. Geogr., 2, 21-32.

Žiedelis, A. \& Masiulis, P. 1969. Recent erosional processes in the slopes of Nemunas Valley. Geography and Geology (Vilnius), 6, 131-150 (in Russian). 


\title{
Vilniuse pinnamoe viimaste aastate muutuste dünaamika uuringud
}

\author{
Regina Morkūnaitė ja Algimantas Česnulevičius
}

On esitatud andmed aastail 2000-2002 toimunud maalihete kohta, mis toimusid tavaliselt pärast sügisesi või kevadisi vihmasadusid, näiteks 2001. a juunis, kui maha sadas 19,8 mm vett, ja sama aasta augustis, mil sademetehulk oli 29,8 ja $37,9 \mathrm{~mm}$. Lähtuvalt pinnamoe kujunemisest, setetest ja nõlvade morfomeetriast, on enamik maalihkeid seotud erosioonilise pinnamoe tüübi $(60 \%)$ ja saviliivadega (80\%). Morfoloogiliselt toimuvad maalihked kõige enam küngastel, mille kõrgus on üle $20 \mathrm{~m}$, nõlva pikkus üle $100 \mathrm{~m}$ ja kaldenurk üle $7^{\circ}$. Artiklis on vaadeldud muutusi 7 loodimisprofiilil, mis asuvad erosioonilises, liustiku servamoodustiste ja glatsiofluviaalsete setete reljeefitüübis. Suuremad pinnamoe muutused toimusid tavaliselt nõlva ülemises ja alumises osas, kust kahe aasta jooksul kanti ära või kuhu kuhjus kuni $35 \mathrm{~cm}$ paksune settekiht. Maalihete poolest eriti aktiivset Rasose-Ribiškèse piirkonda hinnati pinnamoe stabiilsuse koefitsiendi alusel. 